\title{
CORRESPONDENCE
}

\section{Should we make a fuss?}

\section{To the editor:}

In their commentary in the December issue (Nat. Biotechnol. 23, 1479-1480, 2005) Jon Beckwith and Franklin Huang chastise T. H. Morgan for his failure to make a fuss about eugenics in 1915. That year, he gave the Vanuxem Lectures at Princeton University, which were published in 1916. A second edition came out in 1925, and Morgan added a chapter on 'Human Inheritance'1.

을 Clearly, by this time, he was ready to make a fuss, as the selections below (pages 200-207) make clear. They are worth quoting at length, applying just as strongly today as when he made them 80 years ago.

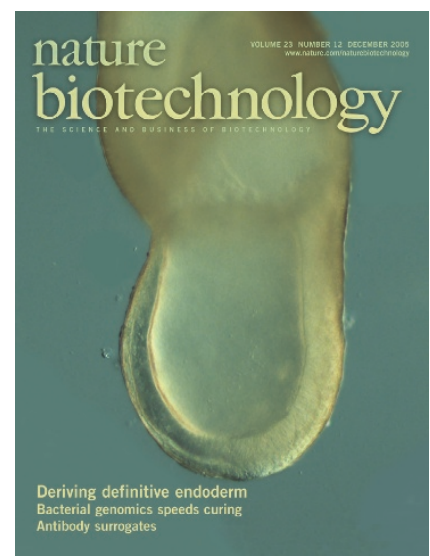

do, to pass judgment as the relative genetic inferiority or superiority of different races.

"If within each human social group the geneticist finds it impossible to discover, with any reasonable certainty, the genetic basis of behavior, the problems must seem extraordinarily difficult when groups are contrasted with each other where differences are obviously connected not only with material advantages and disadvantages resulting from location, climate, soil, and mineral wealth, but with traditions, customs, religions, taboos, conventions, and prejudices. A little goodwill might seem more fitting in treating these complicated questions than the attitude adopted by some of the

Morgan discusses the inheritance of mental traits and writes:

"Social reforms might, perhaps, more quickly and efficiently get at the root part of the trouble, and until we know how much environment is responsible for, I am inclined to think that the student of human heredity will do well to recommend more enlightenment on the social causes of deficiencies rather than more elimination in the present deplorable state of our ignorance as the causes of mental differences."

\section{And later:}

"Least of all should we feel any assurance in deciding genetic superiority or inferiority as applied to whole races, by which is meant not races in a biological sense but social or political groups, bound together by physical conditions, by religious sentiments or by political organizations. The latter have their roots in the past and are acquired by each new generation as a result of imitation and training. If it is unjust 'to condemn as whole people' meaning thereby a political group, how much more hazardous is it, as some sensational writers have not hesitated to modern race-propagandists."

Morgan made these comments just at the time that eugenics was at the height of its popularity and political power. Harry Laughlin, Superintendent of the Eugenics had been giving testimony before the House Committee on Immigration and Naturalization. His reports on 'Biological Aspects of Immigration' (1920), 'Analysis of America's Modern Melting Pot' (1922) and 'Europe as an emigrant-exporting continent' (1924) were an important factor in the passing of the restrictive Immigration Act of 1924.

1. Morgan, T. H. A Critique of the Theory of Evolution (Princeton Univ Press, Princeton, 1925).

\section{Jan A. Witkowski}

Banbury Center, Cold Spring Harbor Laboratory, PO Box 534, Cold Spring Harbor, New York 11724-0534, USA.

e-mail:witkowsk@cshl.edu

\section{To the editor:}

An endorsement of ethical responsibility in science is difficult to oppose. The challenge, however, often is to ascertain Records Office at Cold Spring Harbor, what constitutes an ethical or wise course of action. In their commentary, Beckwith and Huang ${ }^{1}$ allude specifically to a "stirring of the scientific conscience" in the 1960s, including "concerns about the potential dangers of genetic engineering." This example is worth some scrutiny.

In 1974, a small group of scientists requested that the US National Institutes of Health (NIH; Bethesda, Maryland, USA) and the National Academies' Institute of Medicine (IOM) appoint a committee to study the safety of recombinant DNA research, which led the NIH to create the Recombinant DNA Advisory Committee (RAC) later that year ${ }^{2}$. In 1975, this group convened an historic conference at the Asilomar Conference Center in Pacific Grove, California, at which participants called on the NIH to oversee the use of the new research methods more formally ${ }^{3}$.

The conclave focused on the potential risks of recombinant DNA technology, many of them highly speculative. The discussions of risk assessment and management were as much influenced by the brouhaha the meeting provoked in the national media as by a legitimate scientific debate about the likelihood of biosafety problems. There was rampant speculation about laboratory creations run amok, and talk of Frankenstein's monster and Andromeda Strain scenarios enlivened the news (Jurassic Park had not yet been written). Some of those assembled believed that the risks were negligible but that the public needed reassurance in the form of stringent regulation, a recurring (but dubious) theme that persists to this day. Many of the scientists at the meeting appeared to be intoxicated with their unaccustomed celebrity.

According to James Watson, co-discoverer of the double helix structure of DNA and a co-convener of the Asilomar conference, many scientists left the meeting fearing that their colleagues "had compromised their better judgment as scientists just to be seen by the assembled press as 'good guys' (and not as potential Dr. Frankensteins)." 